\title{
Economic evaluation of an industrial biogas system for production of gas, electricity and liquid compost
}

\author{
S. Ghazi ${ }^{*}$, M. Abbaspour ${ }^{2}$ \\ ${ }^{1}$ Islamic Azad University, Parand Branch, Parand, Iran \\ ${ }^{2}$ School of Mechanical Engineering, Sharif University of Technology, Tehran, Iran \\ * Corresponding author. Tel: +982144004586, Fax: +982144865002 \\ E-mail: sanaz_ghazi2001@yahoo.com/ghazy.iau.ir@gmail.com
}

\begin{abstract}
Iran is on the verge of elimination of energy subsidies. This means a sudden increase in prices such as gas, electricity, etc.... On the other hand, the different means of the different means of energy production is a great concern for human being. Amongst all different methods of energy production, renewable energy is paid more and more attention due to the least consequences concerning the diverse climate change effects. However, the economic factors are also important in order to bring a project into reality. In this paper, the potential of biomass energy in an industrial scale is investigated under this great change on national policies. Then the economic analysis of an industrial biogas system in a rural area near the province of Tehran, the capital of I.R.I., as a case study is illustrated .In this process several products will be produced such as organic compost by anaerobic fermentation of agricultural and organic wastes, liquid fertilizer, Methane and Carbonic gases, electricity and heating. The results of economical evaluation shows that the use of methane-fired generators for the production of electricity is economical because of the high amount of biogas production. So, the revenue gained from produced electricity is more than produced compost. Also, in the process of biogas production, the huge amount of Carbonic gas will be produced which can be used after purification in industry. The result show a promising future for the use of bio gas, specially under new policies of zero energy subsidies for households , commercial, and public use.
\end{abstract}

Keywords: Biogas, Economical evaluation, Renewable energy.

\section{Introduction:}

Biogas is a renewable energy source which is produced on the basis of organic waste from the agriculture, food trade industry and households. Furthermore, biogas can be extracted from sludge in the wastewater treatment plants and from landfill sites [1].

Biogas is produced in the process of anaerobic digestion. Anaerobic Digestion is process whereby organic waste is broken down in a controlled, oxygen free environment at certain temperature by using bacteria naturally occurring in the waste material $[1,2]$. Biogas can be extracted from landfill sites by using collection pipes and wells, which uses vacuum to collect the gas. For the gas production from organic waste, sewage sludge and manure, a hermetical digestion tank is needed. Biogas is composed of approximately 50 to $70 \%$ methane (CH4), 30 to $40 \%$ carbon dioxide (CO2), as well as water vapor and a small quantity of nitrogen (N2), sulfur (S) and other trace compounds. Biogas has the same characteristics as the natural gas, which allows using it in the same appliances [2,3]. But its calorific value can be up to two times lower than natural gas. The collection of biogas actually removes pollution from the atmosphere. If the gas is emitted to the air, it would contribute to the global warming as methane is one of greenhouse gases. The impact of methane emissions on global warming is 21 times bigger than that of $\mathrm{CO} 2$ emitted during the burning of biogas [2]. There are many biogas plants all over the world, mainly in USA, India, Mexico, Africa, but as well in Denmark, Sweden, Germany and Austria. It is used for heat production and cogeneration of heat and power, alternatively as well as vehicle fuel in the public transportation [3]. 


\section{Potential of Biomass energy in Iran}

Considering, the availability of all types of Biomass resources in Iran, Power Ministry did a research to evaluate the potential to use biomass for renewable energy. This research was conducted in 1976 and conclusions are as follow [4]:

1- Quantity of accessible Animal Waste in Iran is 74.95 million tons(MT); Biogas could be produced by this amount is 8668 Million cubic meter(MCM) and energy equivalent this biogas is 193299TJ. (TJ $\left.=10^{12} \mathrm{~J}\right)$

2- Quantity of accessible Urban Waste in Iran is 10.6 MT: Biogas could be produced by this amount is 1645.7 MCM.

3- Quantity of accessible Biogas from Urban Waste Water in Iran is 98.85 MCM/day. (Waste Water specifications are: 160 Litter per capita per day and BOD per capita is 33-40 gr/d.c)

4- Quantity of accessible Methane from Industrial Waste Water in Iran is 167.67 MCM/year. Energy equivalent this quantity is 6153TJ per year. (This Waste Water is from Big Food Industry in Iran.)

5-Total gross energy potential from Agricultural and Wood Waste is 411.9 PJ from 3285.5 MCM Methane and 33.95 MCM Ethanol which could be produced [4].

\section{Availability of industrial biogas plants in Iran:}

In Iran, presently two main industrial biogas plants are exist which include Mashhad Landfill Power Plant and Saveh Biogas Plant [5,6].

\subsection{Summary of Mashhad Landfill Power Plant:}

The first Landfill-Gas (LFG) power generation project was initiated in Mashhad, the second largest city in Iran, located on the north east part of Iran, through a memorandum of understanding between "Renewable energy Organization of Iran (SUNA)" and "Waste Recycling and Processing Organization of Mashhad Municipality (WRPO)". Based on the mentioned memorandum, SUNA took the responsibility of preparing technical investigations and tender documents and follow-up the electricity purchase contract between Mashhad LFG power plant and Ministry of Energy. Investment for power plant and commissioning was accepted by WRPO. Feasibility studies, conceptual design and tender documents preparation were consequently allocated to Renewable Energy Department of NRI [5].

The first phase of this project, included design criteria for engineering landfills and gas extraction systems and transmission lines, introduction to energy conversion and power generation technologies for LFG, field investigations and measurement methods and monitoring of LFG. The next phase was feasibility study for installation of power generation unit in Mashhad Landfill, in which, estimation of landfill gas theoretical yield for Mashhad municipal solid wastes, LFG generation modeling and gas flow prediction for long term periods, evaluation of confident power capacity for Mashhad Landfill, technical assessment of power generation equipment for LFG and introduction of more appropriate commercial generating sets for utilization of LFG in Mashhad Landfill, were performed. In the third phase, economical studies, three alternatives were selected on the base of feasibility study results. These alternatives were assessed as economical aspects and finally, installation of generating sets near the guard room of Mashhad Landfill, which is located near to irrigation station and a $20 \mathrm{kV}$ line, was selected as the most useful option for utilization of the whole gas which can be collected through the existing gas extraction systems. The generated electricity in this unit will be sold to power network at an average price of 0.61 dollars per kWh $[4,6]$. 
The phase of conceptual design included: pipeline design for LFG transmission to central gas station, gas blower station, gas treatment process, foundation and structure of generating house, power generation unit arrangement and grid interconnection system plus protection and confidential instruments. Technical characteristics and tender documents were consequently prepared on conclusions [6]. The contract for construction and start-up of Mashhad Landfill power generation unit will be as an Engineering Procurement Construction (EPC) contract. The results of this project shows:

- Pipeline and collection systems were designed on the basis of 13 years useful operation period of a biogas fueled generating set, and LFG generation modeling results, for average gas flow rate of $550 \mathrm{Nm} 3 / \mathrm{h}$ and maximum gas flow rate equal to $660 \mathrm{Nm} 3 / \mathrm{h}$. A minimum power capacity of $435 \mathrm{~kW}$ is expected to be achievable until the end of 2018 by existing gas extraction systems [6].

- The power capacity can be increased to at least $715 \mathrm{~kW}$ if Mashhad municipality develop the gas extraction systems to recent buried layers of solid wastes which are dumped in period of 2004-2006.

- Generating sets with LFG fueled internal combustion engines are the best option for Mashhad Landfill, furthermore, a list of qualified manufacturers of these equipment, has been presented in the project documents.

- Economical assessment results showed the best alternative is the installation of power generating unit in near of Landfill irrigation station.

A case study with capacity of $400 \mathrm{~kW}$ (due to capacity of commercial models) will have the generation cost of electricity relevant to discount rates of $8 \%, 12 \%, 16 \%$ and $20 \%$ equal to: 293, 320, 350 and 0.39 dollars per $\mathrm{kWh}$, respectively [5,6].( It should be noted for the exchange of Rls rate to dollar, one dollar was considered as 10000Rls.)

- LFG power plant interconnection with regional power grid is feasible through the existing $20 \mathrm{kV}$ line in Mashhad Landfill. Electrical circuit drawing and single-line diagram for connection to $20 \mathrm{kV}$ network were obtained and presented in project documents $[8,9]$.

\subsection{Summary of Saveh Power Plant:}

The city of Saveh is in the central province, $150 \mathrm{~km}$ from Tehran with a population of 120,000 . It has a Semi-arid climate and the temperature during different seasons of the year fluctuates within the range of $-10^{\circ} \mathrm{C}$ to $40^{\circ} \mathrm{C}$. In order to establish the Bio-gas power plant in this city, the usable pollutants in Saveh were studied and they were divided into four groups: Household garbage, sludge of sewage treatment, slaughter house waste water and sludge of leaching pit [3]. Through statistical studies, separation operation, sampling and executing physical, and chemical tests, quantity and quality specifications of each of the four types of pollutants were determined. The results are shown in the following tables[6]:

Table 1: MSW Specification[4]

\begin{tabular}{ll}
\hline Parameters & Quantifies \\
Average garbage / day & 78.3 tons \\
Household garbage/ day & 58.7 tons \\
Organic material of garbage /day & 38.2 tons \\
Total solids $(15 \%) /$ day & 5.73 tons \\
\hline
\end{tabular}


Table 2. Specification of sewage treatment sludge[4]

\begin{tabular}{ll}
\hline Parameters & Quantifies \\
Annual average of sludge & 10000 tons \\
Daily average of sludge & 27.4 tons $/$ day \\
Total solids $(1.002 \%) /$ day & $274.54 \mathrm{~kg} /$ day \\
Volatile solids/day & 5.73 tons \\
\hline
\end{tabular}

Table 3: Specifications of the Slaughterhouse sludge[4]

\begin{tabular}{ll} 
Parameters & Quantifies \\
Annual average of slaughterhouse waste water & $4380 \mathrm{~m}^{3}$ \\
Daily average of slaughterhouse waste water & $12 \mathrm{~m}^{3}$ \\
Total solids $(0.508 \%) /$ day & $60.96 \mathrm{~kg}$ \\
Volatile solids/day & $51.39 \mathrm{~kg}$ \\
\hline
\end{tabular}

Table 4: Specification of leaching pit sludge[4]

\begin{tabular}{ll}
\hline Parameters & Quantifies \\
Annual average of discharged sludge from household & 5000 tons \\
wells & \\
Daily average of discharged sludge of household wells & 13.7 tons \\
Total solids $(1 \%$ ) day & $137 \mathrm{~kg}$ \\
Volatile solids/day & $83.57 \mathrm{~kg}$ \\
\hline
\end{tabular}

After determining the quantity and quality of each pollutant separately, anaerobic digestion situation, and the production of Bio-gas from combination feed including above mentioned pollutants, considering the existing real relations in the city in anaerobic reactor at 35 degree centigrade was investigated in a semi-industrial anaerobic reactor.

This reactor is metallic and has a volume equal to 10 cubic meters. In order to control the heat, it is completely isolated and in order to heat up the contents and create suitable heating conditions, the reactor is equipped with an internal coil and a sludge evacuation pump is also installed to mix the content. The reactor has been designed in a way that is the capable of operating both continually and dis- continually (batch). (Fig.1)

In order to study the anaerobic digestion of these feeds on a continuous basis, determining the stoppage time of the material in reactor becomes necessary. Thus, at first, the situation for producing gas in the related reactor on dis- continuous basis was studied. By investigating the volume of daily gas production and the speed of production during the dis-continuous period and the related curve, the stoppage time was determined to be 20 days and for continuous studies the 20 days stoppage was also agreed[8].

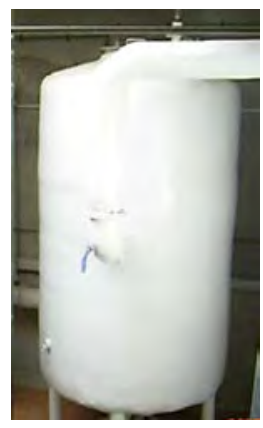

Fig.1. Anaerobic metallic digestion reactor with $10 \mathrm{~m}^{3}$ volume 


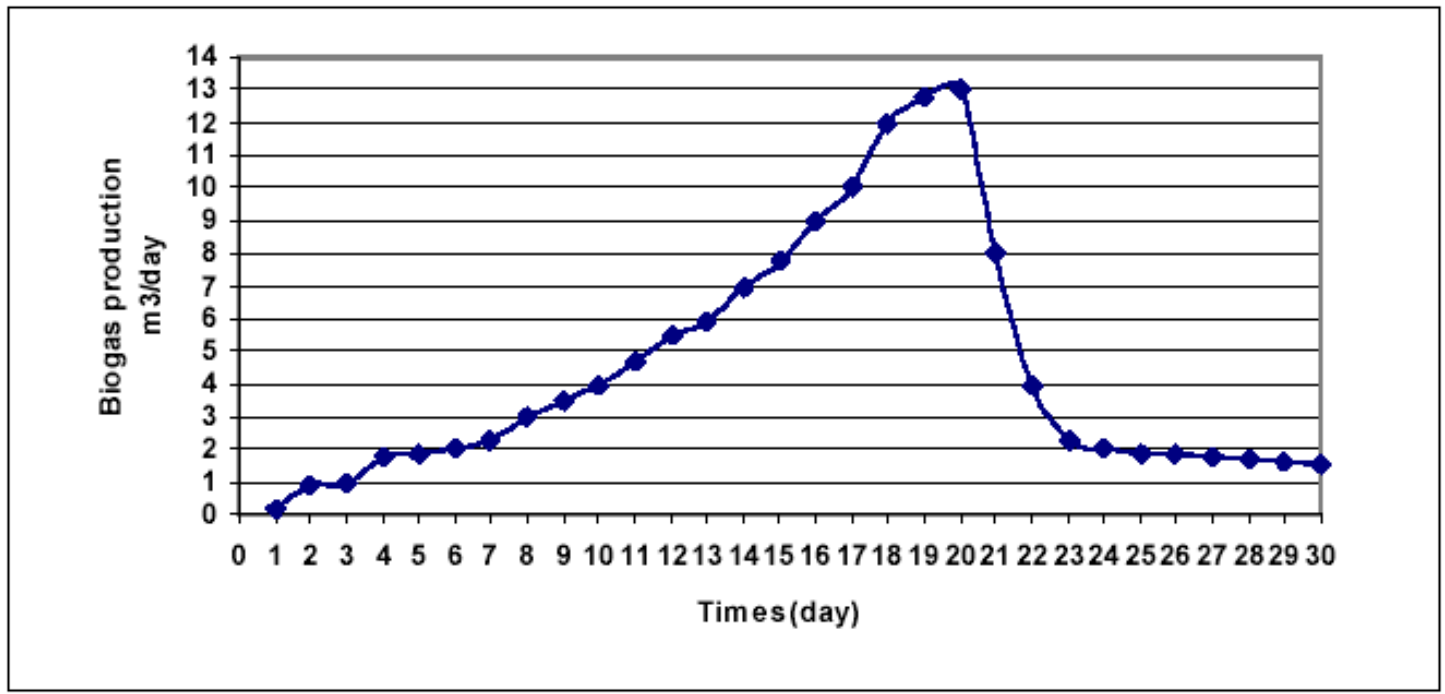

Fig.2. Bio-gas production curve in dis-continuous loading at $35^{\circ} \mathrm{C}[3]$.

Studies during the continuous loading of combination feed including the four groups of urban pollutants with actual existing recording in the city of Saveh shows that for each kilogram of total solid as input, 500 liters of Bio-gas is produced in anaerobic digestion process. Thus on the basis of scientific studies carried out in Saveh Bio-gas power plant, the operation can be summarized as follows:

Table 5. Summary of operation and technical specifications of Saveh power plant [4]

\begin{tabular}{lll}
\hline 1 & $\begin{array}{l}\text { Amount of bio-gas produced for every kilogram of dried } \\
\text { input/ day }\end{array}$ & $\begin{array}{l}500 \text { liter } / \mathrm{kg} \text { of total } \\
\text { Solid }\end{array}$ \\
\hline 2 & $\begin{array}{l}\text { Percentage of T.S in combination feed entering reactor, } \\
\text { including four types of pollutants }\end{array}$ & $6.794 \%$ \\
\hline 3 & Amount of daily input to the power plant & $91.3 \mathrm{ton} /$ day \\
\hline 4 & Amount of Total Solids as input $/$ day & $6202.5 \mathrm{~kg} / \mathrm{day}$ \\
\hline 5 & The most suitable stoppage time in $35^{\circ} \mathrm{C}$ & 20 Days \\
\hline 6 & Total volume of Bio-gas produced/day & $3101 \mathrm{~m}^{3} /$ day \\
\hline 7 & Amount of Fertilizer produced $/$ day & $2500 \mathrm{~kg} /$ day \\
\hline 8 & Extracted water suitable for agricultural irrigation & $31025 \mathrm{~m}^{3} / \mathrm{year}$ \\
\hline
\end{tabular}

\section{Methodology:}

This paper provides a case study for an industrial biogas system to be built on Eshtehard industrial city near the province of Tehran. Since, more than $40 \%$ of husbandries and also an accountable number of settled livestock farming are located in this region, therefore it is possible to collect a total volume of five thousand cubic meters of feedstock per day to feed the system for production of gas, electricity and liquid compost. For feasibility study of this plan, the economical evaluation is considered based on the cost benefit analysis of this project. To calculate the capacity of the system the following assumptions were made:

- The amount of biogas production is equal to 100-160 cubic meter from each ton of organic wastes which can be produced about 170 kwh of electricity and 340 kwh of heating energy. 
- Each 10 cubic meters of biogas can be produced about $15 \mathrm{kw}$ of AC electricity and 35000 kcal of heating water

- Each unit of biogas can produced about 25-30 cubic meter of organic fertilizer per day in 55-60 ${ }^{\circ} \mathrm{C}$ during 15 to 20 days.

- Each cubic meter of organic compost weights 0.7 ton and the weight of 25-30 cubic meters of produced compost is equal to 17.5 or 21 ton.

\section{Results:}

Whereas a lot of husbandries and settled livestock farming are located at Eshtehard region, the amount of substrates for feeding the biogas system could be very high. The estimated amount of substrates at this region is presented at table 6 .

Table 6.The estimated amount of substrates at Eshtehard region

\begin{tabular}{ccl}
\hline Type of substrate & Existing amount & Unit \\
\hline Cattle dung & 219000 & tons \\
\hline Chicken dung & 87600 & tons \\
\hline
\end{tabular}

For design and installation of this project, different parameters such as the total capital cost, number of persons who can be involved in this project, total area for project installations, the amount of electricity, water and energy consumption were calculated for the implementation of this project.

- The required area for biogas unit installation is equal to 136,000 square meter at Eshtehard industrial region which is located near to the more than $40 \%$ of husbandries and also an accountable number of settled livestock farming of the country

- Total capital cost is assumed as 22.8 million dollars

- The total number of persons for this project include 103 persons as a producer and 43 persons as a supporter

- The power of consumed electricity is equal to $259 \mathrm{kwh}$ of total $5950 \mathrm{kwh}$ of electricity which is produced by the biogas unit. Total production capacity of products is presented in table7.

Table7. Total production capacity of products

\begin{tabular}{lccc}
\hline Type of product & $\begin{array}{c}\text { Amount of } \\
\text { production(per hour) }\end{array}$ & $\begin{array}{c}\text { Amount of } \\
\text { production (per year) }\end{array}$ & Unit \\
\hline Electricity & 5950 & $52,122,000$ & $\mathrm{kwh}$ \\
\hline Carbonic gas & 2.36 & $20,673.6$ & ton \\
\hline Heating & 11900 & $104,244,000$ & $\mathrm{kwh}$ \\
\hline Cattle dry compost & 7.98 & 69,934 & ton \\
\hline Chicken dry compost & 3.193 & 27,959 & ton \\
\hline Liquid compost & 58.8 & 515,288 & Cubic meter \\
\hline
\end{tabular}

It should be mentioned, from the total amount of produced electricity, 250 kwh consumes for the biogas system and the rest can be delivered to grid electrical network. Also, the produced dry compost which contain 35\% humidity can be packed for domestic consumption.

- The annual amount of consumed water is equal to 342144 cubic meter which can be used for agricultural land after an anaerobic fermentation process. 
- The annual amount of consumed energy is equal to 1,569,000 litres of gasoil for combustion of electrical generator and 21,900 litres of gas for the vehicles during the installation of plant

Based on the mentioned characteristics, the following economical parameters were calculated for the presentation of economic analysis of this project. The calculate amount of these parameters were shown in table8.

Table8.Economical evaluation of this project based on financial calculations

\begin{tabular}{ll}
\multicolumn{1}{c}{ Financial parameter } & \multicolumn{1}{c}{ Estimated cost (Dollars) } \\
\hline The amount of fixed investment & 22 million Dollars \\
\hline The amount of investing turnover & 0.85 million Dollars \\
\hline Total amount of investment & 22.9 million Dollars \\
\hline Actual cost of products in & 0.36 Dollars per kwh of electricity \\
final capacity & 87.5 Dollars per ton of Carbonic gas \\
& 26 Dollars per ton of Cattle dry compost \\
& 65 Dollars per ton of chicken dry compost \\
& 3.5 Dollars per cubic meter of liquid \\
compost \\
\hline The amount of total sale in final capacity & 13 million Dollars \\
\hline Annual return of investment & 3.4 million Dollars \\
in final capacity & \\
\hline Return investment time & 3.3 years \\
\hline Rate of return & $0.22 \%$ \\
\hline Per capita investment & 0.17 million Dollars \\
\hline It should be noted for the exchange of Rls rate to dollar, one dollar was considered as 10000Rls.
\end{tabular}

As the above table illustrates, the time for capital cost return is equal to 3.3 years and the amount of earnings after this time is about 3.9 million dollars.

\section{Conclusions:}

The aim of this project is the conversion of low-value organic wastes to organic compost with high value at industrial scale based on anaerobic fermentation. The anaerobic digestion has numerous advantages rather than aerobic digestion. The most advantages include:

- The value of the produced compost is so high rather than traditional fertilizer. For example by the use of this compost the production of agricultural crops such as corn and tomato can be increased respectively up to $49 \%$ and $35 \%$.

- Elimination of pathogenic bacteria, viruses, agents and odour in anaerobic digestion

- The huge amount production of methane and carbon dioxide gases. Methane gas can be used to produce electricity with the use of methane burner.

Calculation indicates that it is possible to produce $5950 \mathrm{kw}$ electricity which $250 \mathrm{kw}$ should be consumed for the process itself. This system can produce 2.36 tons of gas, 58.8 cubic meters of liquid compost, 11 tons of dry compost and equivalent of $11900 \mathrm{kwh}$ of heat per hour. The results of economic analysis shows that this project can be beneficial and economical in a short time period. Finally, with consideration of economical, environmental and social issues, the promotion of this types of industrial biogas system can be an attractive project at regional and national level. 
For accelerating the execution of this kind of projects in Iran and similar developing country, the following recommendations are suggested:

- As discussed, the elimination of energy subsides help the rapid development of this kind of renewable energy systems. The government can encourage the use of these systems by setting the purchase policy for the electricity production from these systems. To do so, some technical steps should be carried out to make this action possible.

- It is necessary to implement some policies to encourage the private sector participation in this issue.

- It is necessary to imply some policies to increase the awareness of decision makers, especially managers, authorities and experts about the benefits and advantages of this kind of energy.

- The CDM mechanism was not brought into account in this study. However, the implementation of CDM mechanism can help to have even a better outlook using this type of energy system.

\section{References}

[1] The renewable energy organization of Iran, "biogas and development", 4th national conference on renewable energies, 2001,pp. 80-88

[2] GH. A.Omrani, "The principal of biogas production from urban and rural waste", 2000, pp. $125-142$

[3] The renewable energy organization of Iran, "The practical use of biogas unit in Kish island"2006, pp. 54-67

[4] I, Nahvi , Z. Sahbaee, "Biogas production and its role in the control of the environmental pollution”, Proceeding of 4th seminar of bigas in Iran, 2008, pp. 145-152.

[5] http://www.iranenergy.org.ir

[6] http://www.suna.org.ir

[7] J.Wiley, "Biogas from waste \& renewable resources"2008, pp 167-173

[8] D.House, "Biogas handbook",2006

[9] J.Barrie, "Everything biogas", 2009 